\title{
The Archaeology of Myth: Rock Art, Ritual Objects, and Mythical Landscapes of the Klamath Basin
}

\author{
Robert J. David, Department of Anthropology, University of \\ California, Berkeley, 2251 College Building on Campus, Berkeley, \\ CA 94720-1076, USA; and 3337 SE 53rd, Portland, OR 97206, USA \\ E-mail: dave2u@berkeley.edu
}

\begin{abstract}
Recent research in the Klamath Basin has shown that rock art and landscape are intimately connected, mutually informed by indigenous notions of sacred places. Modeling this landscape has been possible through an understanding of Klamath-Modoc myth. This has led some researchers to derive general interpretations of the rock art that are largely in agreement with Klamath-Modoc spiritual beliefs. I take this approach a step further and propose interpretations for specific rock art images and ritual objects, arguing that oral traditions harbor the fundamental logic that underpinned shamanic rituals that led to the creation of these paraphernalia.
\end{abstract}

Résumé: Une recherche récente dans le basin de Kalmath a montré que l'art rupestre et le paysage sont intimement liés, mutuellement marqués par les notions indigènes d'endroits sacrés. Il a été possible de modéliser ce paysage grâce à une compréhension du mythe de Klamath-Modoc. Cela a permit à certains chercheurs de tirer des interprétations générales de l'art rupestre qui sont en grande partie en accord avec les croyances spirituelles de Klamath-Modoc. Je considère cette approche plus en avant et je propose des interprétations pour les images rupestres spécifiques et objets rituels, soutenant que les traditions orales entretiennent la logique fondamentale qui a étayé les rituels chamaniques qui ont permit la création de ces attirails.

Resumen: Recientes investigaciones en el Klamath Basin han demostrado que el arte rupestre y el paisaje están íntimamente relacionados y que se han conformado mutuamente a través de las creencias indígenas sobre los lugares sagrados. El modelado de este paisaje ha sido posible gracias a que hemos comprendido el mito de Klamath-Modoc. Esto ha llevado a algunos 
investigadores a hacer interpretaciones del arte rupestre muy en consonancia con las creencias espirituales de Klamath-Modoc. Llevando este enfoque un paso más allá, propongo interpretaciones para las imágenes específicas del arte rupestre y los objetos rituales, argumentando que las tradiciones orales recogen la lógica fundamental subyacente a los rituales chamánicos que han dado origen a la creación de esta parafernalia.

\section{KEYWORDS}

Klamath Basin rock art, Oral tradition, Mythical landscape

\section{Introduction}

My purpose in this paper is to demonstrate how Native American mythic narratives may be used to enhance and inform interpretations of rock art and ritual objects within a limited cultural context. Specifically, I explore the relationship between shamanic ritual and the myths of the KlamathModoc peoples who today still live in the Klamath Basin of southern Oregon and northern California.

The incorporation of Native American myth to archaeological research has generated much discussion surrounding its utility and reliability in a number of archaeological circumstances. Echo-Hawk (2000) urges archaeologists to treat oral traditions as a valuable category of data that can be used in conjunction with other lines of evidence to obtain a richer, deeper reflection of ancient America history and Native American ancestry. Illustrating his position, Echo-Hawk traces connections of multiple groups, including the Puebloan, Caddoan, Numic, and Athapaskan, for historical roots in the Blue Mountains of Colorado. Reviewing origin and migration narratives, Echo-Hawk compares the archaeological evidence, not for an exact correspondence between the story elements and the archaeological records, but rather for the long-term historical processes of complex interactions that gave rise to the Wichitas, Pawnees, and Arikaras. "We should not look too hard for Pawnees, Arikaras, or Wichitas, in the archaeological data of the Blue Mountains," he says. "[Instead], we should seek to understand the elaborate dynamics of regional population interactions to grasp the formation of later tribes" (Echo-Hawk 2000:283). In Echo-Hawk's view, the inclusion of oral traditions should be used to reconcile diverse realms of information and build workable models of the past. 
Mason (2000), by contrast, argues against the incorporation of oral tradition into archaeological research, based largely on four main arguments. First, he says, oral traditions "are dependent on memory and verbal transmission, and thus are simply not trustworthy" (2000:256). Second, oral tradition today is, by its nature, "more an artifact of contemporary culture than a record of the past" (2000:259). Third, because oral traditions are closed belief systems, they are "beholding to authority and impervious to external challenge" (2000:259). Finally, "all or parts of oral traditions may be considered sacred, and thus only partly or not at all accessible to outsiders; guardians of such lore determine what may be released and how it may be used, making it an incomplete and thus unreliable data set" (2000:259-260). Mason points out that "achronology is one of the concomitants of an oral non-literate society." This presents a conundrum to researchers whose interest depends on accurate chronologies (Mason 2000:260). Although he concedes that oral traditions are not always irrelevant, he urges careful evaluation of sources and cautious application, saying that those who pick and choose what they will use from oral tradition are "cherry picking in a minefield" (Mason 2000:262).

Anyon agrees that care should be taken when incorporating oral traditions into archaeological research but points out that archaeologists should be able to decipher "real" history from other aspects of oral traditions using modern technology and methods. Native American oral traditions contain information about cultural values, beliefs, natural features, specific sites, and landscapes that are important cultural resources for Native Americans (Anyon et al. 2000:63). Moreover, they are intimately connected with religious beliefs and knowledge. These benefits, according to Anyon, cannot be ignored (Anyon et al. 2000:64).

All authors present valid points that foreground contentions that go well beyond the scope of my topic. Thus, I do not treat the debate to any real extent here except to say that I agree in large part with Anyon. While Mason is concerned with oral tradition's chronological reliability, Anyon and Echo-Hawk's position seems to favor its use as a supplemental interpretive device. This is also my position. This stated, I will focus specifically on how the behavior of mythical beings described in Klamath-Modoc narratives are an important information source for understanding the form and location of rock art and ritual objects in the archaeological record. It is in these narratives that the fundamental logic underlying shamanic rituals resides. Shamans consulted these characters as important players in their rituals. The exploits of fantastic characters define the nature of their supernatural qualities and thus justify their positions in the shamans' pantheon of medicine spirit-helpers. 
Fortunately, the mythic narratives of the Klamath-Modoc people have been well-documented. In the early 1880s, the husband and wife ethnographers from the Bureau of American Ethnology in Indian Territory, Jeremiah and Alma Curtin, were working with the Seneca Indians in Oklahoma when they chanced upon the Modoc exiles from the Modoc War of 1873. One woman in particular, Ko-a-lak'-ak'a, provided the Curtins with incredible amounts of detailed information from memory in the form of mythic narratives which they translated and wrote down verbatim. Later, they published an edited selection of stories in Myths of the Modocs (Curtin 1912), while the bulk of their material remained in their unpublished manuscripts. Writing at different times, Gatschet (1890a) and Barker (1963) also recorded a number of Klamath narratives from Klamath informants living on the then Klamath Indian Reservation. Many of these are identical to Curtin's Modoc myths, suggesting that the narratives from both tribes have potential use in this study on Klamath Basin ritual materials. Understanding the nature of the mythical personae in these narratives, and the behaviors they exhibit, will illuminate the shamanic ritual procedure and provide interpretive value for Klamath-Modoc shamans' rock art and ritual objects.

\section{Background Context}

The Klamath Basin of southern Oregon and northern California is the geographic focus of an ongoing research program about Klamath and Modoc Indian rock art. The region is a semi-arid, high desert landscape watered by light annual precipitation and mountain runoff. Its elaborate system of lakes, marshes, and streams has provided rich habitat for the Klamath and Modoc Indians for at least the past 6,500 years (Cressman 1956:463, 470; Stern 1966:4).

Although their territories lie adjacent to one another, the Klamath and Modoc Indians consider themselves discrete groups, and certainly, pre-contact, were identity-conscious differentiated subgroups. Before the treaty of 1864 mandated that they be combined on to a single reservation, both tribes were organized into a collection of tribelets scattered along their homeland waterways (Figure 1) and were bound together by a common language, religious system, and familial alliances (Gatschet 1890a:xxxiv; Spier 1930:21-23; Stern 1966:19; Fixico 1998:80). In the north, the Klamath occupied a core homeland that centered largely on the Upper Klamath Lake and in the Williamson and Sprague River systems (Spier 1930:8-10; Jensen and Farber 1982:21-22). In the south, the Modoc occupied settlements around the Clear and Tule Lakes and the Klamath and Lost River systems. 


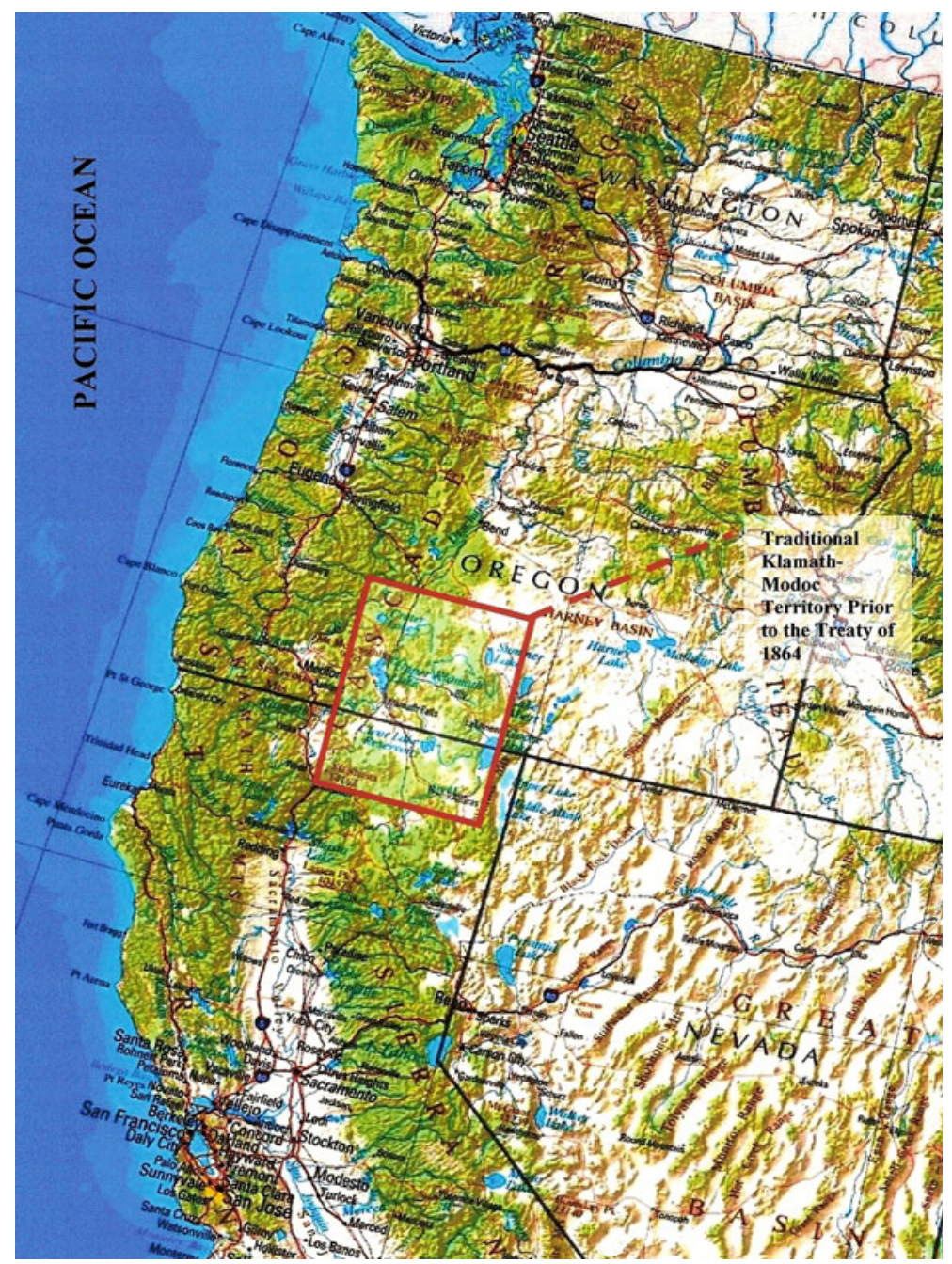

Figure 1. Map of Klamath-Modoc territory before the Treaty of 1864, outlined in red. Map based on description of territory boundaries from Article I of the said treaty. From, Perry Castaneda Library Map Collection. University of Texas Libraries. http://www.lib.utexas.edu/maps/united_states/oregon_90.jpg

Religion for both groups was based on shamanism. In Klamath society, everyone sought spirit power at least once in their lifetimes (Spier 1930:93-95). Among the Modoc, spirit power was exclusively a shaman's enterprise (Ray 1963:31). Among both groups, shamans were individuals who had acquired more than usual spirit power and whose primary role 
was curing. Because illness was thought to derive from supernatural causes, shamans affected cures through the use of supernatural treatments and "medicine tools", which Spier (1930:109-110,142) refers to as "mu'lwas", or shaman's paraphernalia. Possessing spirit power was fundamental to the shamanic practice. The curing ritual was generally a three-fold observance, beginning with the preparation period, followed by the diagnostic procedure, and concluding with the curing procedure (Ray 1963:55; Spier 1930:122-131). Obtaining a proper diagnosis required the correct assembly of medicine spirits, which shamans achieved through the use of ritual paraphernalia and incantations. Once assembled, the spirits would debate amongst themselves through the person of the shaman until the culprit was exposed. Only then could the assemblage decide on a cure (Ray 1963:46-47).

The medicine spirits consulted by shamans are the same characters described in the mythic tales (Spier 1930:133). Gatschet explicitly states

It would be a mistake to assume that the animals which the folklore of the Indian in the hunter stage chiefly celebrates are game animals or of such as are of material advantage to him. Folklore selects for its purpose such beasts which the hunting and fishing Indian, with his great practical knowledge of animate creation, admires above others for such qualities as their surprisingly sagacity, their wonderful agility, the love for their offspring, the help afforded by them by discovering the hidden causes of disease, the beauty of their skin or other covering, and the change in the coloring of their fur-skins wrought by the alternation of the seasons-or such animals as he dreads on account of their ferocity, their nightly habits, their power of bringing about storms, thunder, or rain-fall, and last, but not least, for their demoniac power of presaging future events, especially war, disease, and death. The great scarcity of certain anaials is also a a sufficient cause for introducing them into the popular stories (Gatschet 1890a:c).

Notably, Gatschet concludes that "the animals which form the subject of mythic stories and beast tales are pretty much the same as those mentioned in the magic songs of the medical practitioners..." (emphasis mine) (Gatschet 1890a:c-ci).

In the light of this information, it is surprising that so little effort has been made in the Klamath Basin to explore their potential for interpreting rock art and ritual objects. I proceed with following assumptions. The first derives from a letter written by Dennison (1878), who reported that rock art was still being produced [in 1878] and was considered to be sacred (see Whitley et al. 2004:224). Whereas this is within just a few years of the Curtins' visit to Oklahoma, where they collected mythical narratives from Koalakaka, I assume that the myths and the rock art are contemporaneous, despite the rock art's demonstrated time-depth (Armitage et al. 1997). 
My second assumption stems from Gatschet's (1890a:c) connection between mythic creatures and shaman's spirit-helpers. It seems reasonable that that the same mythical characters-animals and anthropomorphic beings alike-are the very characters (and hence, medicine spirits) represented in the rock art.

\section{Previous Research}

\section{Rock Art}

Before the mid-20th century, rock art in the Klamath Basin received relatively limited scholarly attention (Abbott 1857; Mallery 1893; Sterns 1928; Cressman 1937). In the late 1950s and early 1960s, however, Swartz (1978) recorded some 119 sites for the Klamath County Museum, conducting the most comprehensive analysis to date and bringing this large corpus of rock art into scholarly discourse. In Klamath Basin Petroglyphs Swartz sought to reconstruct the culture history of the region's rock art by amassing a body of rock art material and employing it to study changes in rendering practices through time and space. Swartz considered ethnographic information to be of little value in his study and gave it little consideration in his study (Swartz 1978:14). Only recently are researchers realizing the importance of ethnographic literature (including myth) in rock art interpretation.

Writing in 2004, Whitley et al. focused on rock art of the Modoc Plateau as an expression of "landscape symbolism," drawing particularly on ethnographic and mythological narratives to inform their interpretations. Developed by Whitley (1994), the landscape symbolism model considers how the distribution of supernatural power structured the spiritual relationship native people shared with their physical surroundings (Whitley et al. 2004:221-223). Rock art, according to the model, occurs at sacred places and are expressions of the spirit power believed to be in residence therein. Whitley et al. (2004) applied this approach to three Modoc rock art site complexes to present their case. Imagery at these sites is characterized by the same dots, straight lines, circles, zigzag and stick-figure anthropomorphs found throughout the Klamath Basin. Congruent with the predictions of the landscape symbolism model, the rock art sites are situated on relatively low ground and at places Klamath-Modoc people believed to be imbued with supernatural power (Whitley 1994).

The Schonchin Butte sites, the first group in their study, appear to derive their sacred properties from mythical events. Specifically, the tale, "The Old Man Who Turned into a Screw" (Curtin nd, myth-019), concerns old man Lulusdewieas who, following poor treatment from his daughter-in-law, went outdoors and sat down at the south end of the 
house. As he sat, his penis swelled and he painted it black. Suddenly, it turned into a screw and in the course of events he bore out the lava tubes that today characterize the Lava Beds National Monument (Whitley et al. 2004:228-229).

The most obvious relationship the rock art at these sites shares with the story is the color of the paint: all of the images are made from black paint (Figure 2) (Whitley et al. 2004:227). But another important aspect is the sexual symbolism involved in the creation of the lava tubes themselves. Whitley (1994) has noted before that sexual symbolism is an important component of landscape symbolism and is used metaphorically to describe ritual trance. The reference to sexual intercourse between the old man and the earth in this story connects the creation of the rock art to the ritual trance of Lulusdewieas, who, according to Whitley, represents a shaman. This is because the old man's name, Lulusdewieas, derives from the Modoc word Lulus which means "medicine" (Whitley et al. 2004:228). Notably, all of the supernatural properties shamans attributed to these lava tube sites are encoded in the mythic tales. One story in particular tells how G'mokamc specifically instructed his son Aysis to go to the lava beds to find spirit power, thereby indicating that this site was specifically identified as containing supernatural power (Whitley et al. 2004:229).

The second site in their study is Petroglyph Point, located near Tule Lake, California. The face of this atypical cone-shaped volcano is covered with more than 5,000 petroglyphs and has been dated tentatively by Heizer and Clewlow (1973) to between A. D. 500 and 1600 (Figure 3). According to Klamath-Modoc myth, this volcanic outcrop is the point where G'mokamc created the physical world (Ray 1963:18). From Whitley's

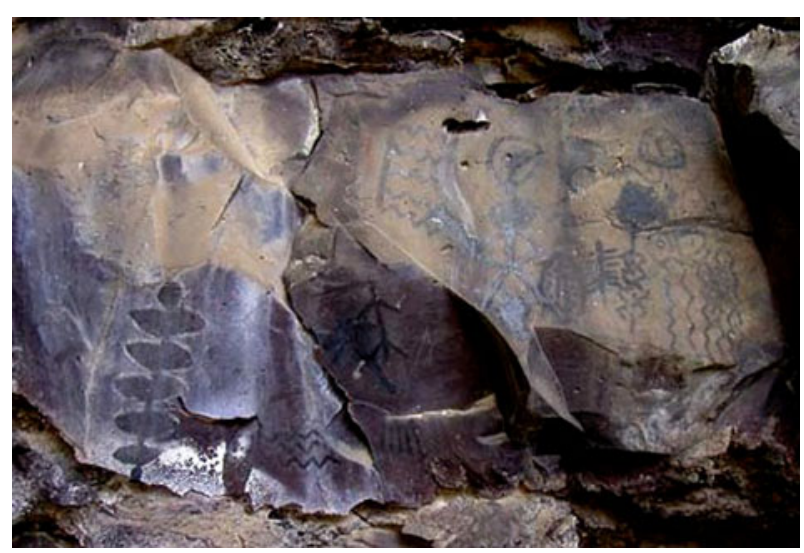

Figure 2. Black-painted pictographs from the Schonchin Butte site complex corresponds well with the mythological description of the creation of the lava tubes 


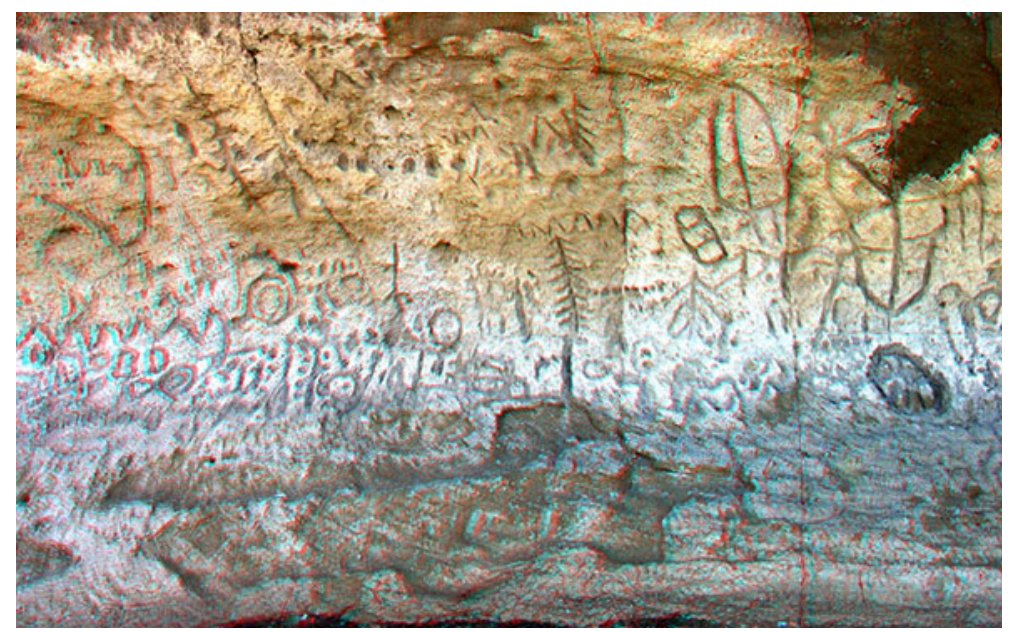

Figure 3. Incised petroglyph designs at Petroglyph Point, Lava Beds National Monument, California

landscape symbolism perspective, not only does its position on the lowest part of the Modoc landscape reflect the gendered symbolism of model (e.g. high:masculine/low:feminine), but once again in the mythology they could find a justification for the existence of this sacred place. Accordingly, the rock art here derives from the site's association with G'mokamc and the creation of the Klamath-Modoc world (Whitley et al. 2004:230).

The third site in their study, G'mokamc's House, is the same small cave located near the top of a high butte overlooking Tule Lake examined by Hann and Bettles below (2006), noting that it was from this point G'mokamc instructed his son Aysis in the ways of spirit medicine and sent him off on a series of vision quests in order to become a powerful shaman (Curtin n.d., myth-107, cited in Whitley et al. 2004:231). The circle and zigzag images decorating the interior walls of the cave are consistent with the imagery found at all other locations in the region. The authors focus specifically on the emblem of G'mokamc's power, the sun disk, which he wore on his back. They argue that the circular motifs dominating the art style refer specifically to G'mokamc's symbol of power. They suggest that this cave was one in which shamans went to access the spirit power of G'mokamc himself and that creating the rock art inside the cave was a part of their ritual process (Whitley et al. 2004:231-233). Once again the supernatural power attributed to these sites can be connected to specifics in myth.

Guided by what they termed the "myth cycle", Hann and Bettles (2006) also examined the G'mokamc's House site. Ethnographic accounts identified 
this site as a shaman's cave (Hann and Bettles 2006:186-187). Like Whitley et al. (2004), Hann and Bettles noted that the location of the cave corresponded well with the sacred geography described in Klamath-Modoc mythology (Hann and Bettles 2006:183). Of particular importance to their study was Modoc Myth 107 (Curtin n.d.), in which G'mokamc, the Klamath-Modoc creator, sent his son Aysis from his "house" to seek spirit power from various parts of the region. Resting in the center of the Modoc homeland, this cave forms the focal point of their study. Rock art designs cover the cave walls and include incised lines, curvilinear meanders, v-shaped images, circles, and concentric circles. More importantly, however, G'mokamc's House, according to myth, is the place where he and his daughter settled after an ordeal in the land of the dead, in which he resurrected her and brought her to the "upper world" where he created humankind (Curtin 1912:44-45). Accordingly, Curtin attributed the cave's function as a site where young women embarked on their puberty quests as well (Curtin 1884:book 8/myth 15, cited in Hann and Bettles 2006:188). That G'mokamc's daughter had embarked on her own puberty quest prior to her retirement to the cave is very likely significant to its use as a women's puberty quest site. Hann and Bettles (2006) conclude that every aspect of that site has mythical warrant.

Taking a slightly different approach at about the same time, I studied a sample of eight Klamath sites farther north and concluded that Klamath Indian rock art was related to shamanic rituals involving G'mokamc (David 2005a:60-65). Notably, the rock art panels in my study area tended to face west, which was the direction of the land of the dead. This was not true for the sites studied by Hann and Bettles (2006) or those by Whitley et al. (2004). Reasoning that G'mokamc's primary role in myth was traveling to the land of the dead and bringing the dead back to life (see Hann and Bettles 2006:183), I proposed that the circular designs dominating Klamath rock art represented his sun disk (Figure 4) and that the art was a visual and material feature in a curing ritual in which shamans staved off otherwise certain death with G'mokamc's power (David 2005a:58-59). Though I did not realize it at the time, subsequent research has suggested that the backbone of Klamath-Modoc cosmology is constituted and substantiated by myth, while mythology itself is made palpable, even tangible by, the material practices of rock art, and the making and using of ritual objects. But while it has been shown that rock art sites are distributed along important mythical loci, I take this a step further and argue that at least some rock art characters themselves derive directly from the mythical tales as well (David 2005b:17-19). The same mythological connotations are also true for ritual objects. 


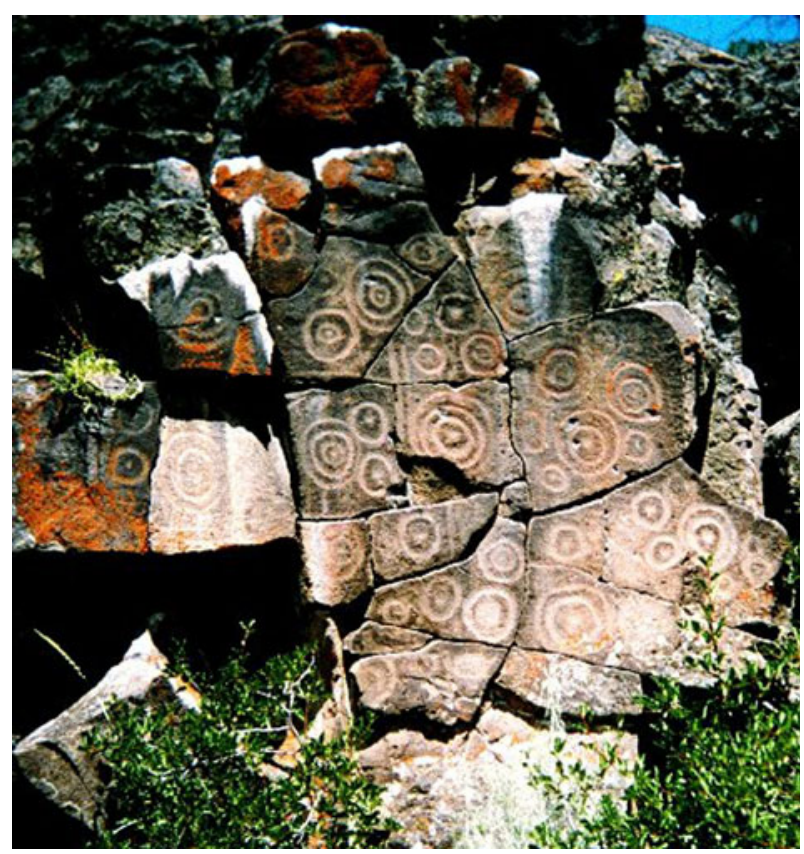

Figure 4. Circular designs dominate the Klamath-Modoc rock art style

\section{Henwas}

Henwas are curious anthropomorphic statuettes that have been found largely in stream banks in the heart of Klamath Indian territory. Little information has ever been gathered about these objects and no archaeological investigations have been undertaken. Author Carrol B. Howe, a former Klamath County School District Commissioner, noted the first non-indigenous encounter with these objects. In his book Ancient Tribes of the Klamath Country, he described how Klamath County Commissioner Scott Warren found a henwas while fly fishing on the Williamson River. Submerged in about two feet of water, Warren spotted an algae-covered stone that exhibited two sharp points that resembled horns (Figure 5). He described it to Howe as a "stone idol" and took it to the Klamath County Museum for identification. There, curator Roy Carlson identified it as a henwas and told him that he himself had purchased a collection of them from Klamath tribal member "Lizzie" Kirk some years before. Kirk and other informants called them "henwas," which they interpreted as "rocks standing upright" (Howe 1968:139, 141). Carlson began an immediate search for information about the stone objects and published his findings 


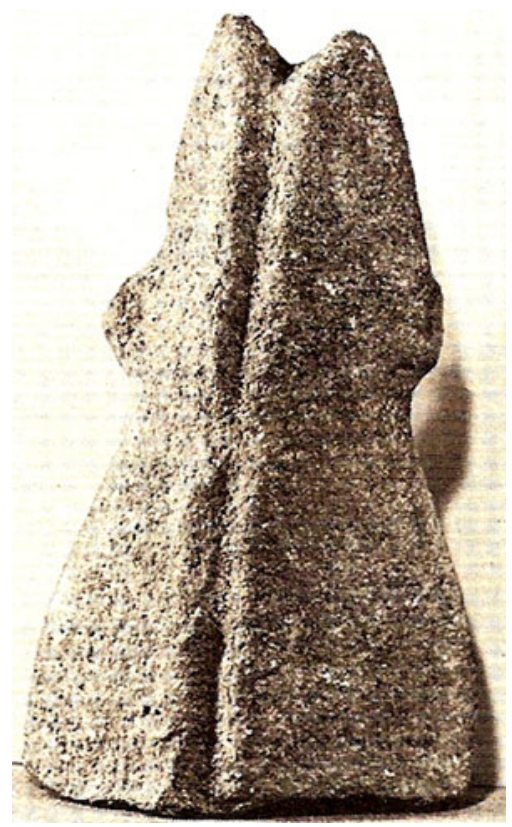

Figure 5. The "Chiloquin" henwas found and collected by Klamath County Commissioner Scott Warren. From Howe (1968:138), Figure 108

in the American Anthropologist (Carlson 1959). Kirk told Carlson that the figures were used by the "Indian Doctor" and had the ability to move by themselves. Carlson also noted that ethnographer Albert S. Gatschet translated the term henwas to "a rock standing upright" and said that they are the subject of myth and shamans' incantations (Gatschet 1890a:179; 1890b:62, cited in Carlson 1959:88) and thus played a role in some ritual. Spier (1930:106) commented briefly on a henwas associated with the cremation cemetery at Duno'kai village on Pelican Bay, referring to them as "shaman's stones" and saying that they were believed by the Klamath to be once living things that were transformed to stone when Crow laughed at them (Carlson 1959:88).

Another bit of information collected by Carlson came from a catalog entry for a henwas in the Hearst Museum of Anthropology at the University of California, Berkeley. Received in 1908, the specimen is cataloged as a "hen-was" with a note stating that "doctors" used the item ceremonially (Carlson 1959:89). In nearly every account given by Carlson, henwas were identified as medicine objects used by shamans and harbored supernatural properties. I will demonstrate that the properties derive warrant from Klamath-Modoc mythic narratives. 
Despite the availability of ethnographic materials at hand, however, little is known about how henwas were used in particular shamanic rituals. Mythology has been a long overlooked source of information for interpreting the meaning and function these ritual objects. We are fortunate in the Klamath Basin to have an extensive collection of myths that can shed light on these ritual phenomena. Mythic narratives sources not only provide additional information for particular objects and symbols, but may also help to define the ritualistic structure in which they functioned. In essence, it appears as if mythical narratives harbor the logic that underpins the structure of shamanic ritual. In order to pursue this idea further, I have undertaken an effort to study a combination of ethnographic information and myths and use this information to suggest interpretations for selected Klamath Basin henwas and rock art images.

\section{Methods}

Numerous resources needed to be consulted for this study, including Klamath-Modoc myths, various ethnographic texts, and academic papers. Existing site reports from the USDA Forest Service and the Klamath County Museum were consulted, and I also reviewed the interview transcripts of tribal elders from my 2005 master's thesis project. That is, the research project is explicitly incorporating several lines of evidence, not just trying to read back and forth between the rock art images, their locations, and the mythology.

Our fieldwork consisted of a series of site visits in southern Oregon in the spring and summer of 2005. The sites were surveyed and documented using forms specially designed to directly address project concerns. We used standard government compasses and topographic maps to determine the orientation of the rock art sites and individual panels. Rock art images were photo-documented using standard $35 \mathrm{~mm}$ film, with each panel receiving a temporary number for filing purposes. Later, in the laboratory, I stipple-traced the images from the photographs in order to minimize the disk space required for their inclusion in this article. Stipple-tracing did not take place in the field at the request of the Klamath Tribes Culture and Heritage Committee, whose members did not want the rock art images touched in any way, even by myself, a member of the Klamath Tribes. Most of the information describing the way rock art is informed by shamanic ritual, resurrection, and the land of the dead has been discussed in David (2005a) and is briefly reiterated in the previous section. For a fuller discussion, readers should consult not only my own work, but also that of Hann and Bettles (2006), Whitley et al. (2004), and Hann et al. (In Press). 
Information about henwas is far more limited than rock art, probably due in part to the fact that none have been recovered in an archaeological context. Nevertheless, they have been ethnographically identified as ritual objects by a number of authors and researchers who connect them simultaneously to both ritual and myth (Gatschet 1890a:158, 179; Spier 1930:106, 143; Carlson 1959: Howe 1968:139, 14; 1979:180-184). Moreover, the single scholarly article made available for initial understanding, as reported above focused on a collection of henwas purchased from a Klamath tribal member who in turn gave him their information about their meaning. Information concerning henwas has been gathered largely in the context of early twentieth century collecting activities. Nevertheless, what little there is appears to be consistent with the shamanic belief system of the KlamathModoc people and thus provides sufficient interpretive value for our present purposes, as I begin here to draw together evidence in support of my thesis.

In preparation for the following discussion, an explanation concerning the language utilized in the myths is essential. In particular, the terms "wives" and "husbands" used in these stories should be taken as synonymous in meaning with "medicine spirit". Although this is never explicitly stated, it is certainly demonstrated. Whenever a character in the mythic tales selected a spouse, the selection was based not on the values dictated by traditional spousal roles in the Klamath-Modoc household, but on the merits of their supernatural abilities. In the story G'mokamc and ?aysis (Aysis) (Barker 1963:37-45) Butterfly rescued Aysis from certain death stranded in a tall tree and nursed him back to health using shamanic cures, such as rubbing him down with bear's fat. Grasshopper and Porcupine assisted her, and they all become "wives" of Aysis (Curtin 1912:14; Barker 1963:41-45). In another tale, Gaukos (who is also Aysis, the moon) selected Weketas, a big ugly frog woman, from among the prettier frog sisters because of her ability to resurrect him from the dead (Curtin 1912:82). The common factor exhibited by these characters is their supernatural abilities that demonstrate their value as able medicine spirits. Accordingly, the "spouse" of a dominant medicine spirit is just as likely to appear in the rock art as the dominant medicine spirit itself. Figure 6, for example, shows the "Butterfly" rock art site, so named because of the predominant figure etched into the pre-painted rock face. Remembering that the Butterfly spirit brought Aysis back to life in the myth described above, the engraved butterfly in Figure 4 may be thought of in this context as the "medicine spirit" Aysis; for she was the agent of his recovery. Similarly, the grasshopper image in Figure 7 also bears a direct reference to Aysis since Aysis acquired a new grasshopper "wife" in the same story. In short, both of these images represent the resurrecting power of Aysis, because he is the dominant spirit to whom they were "espoused". A shaman 


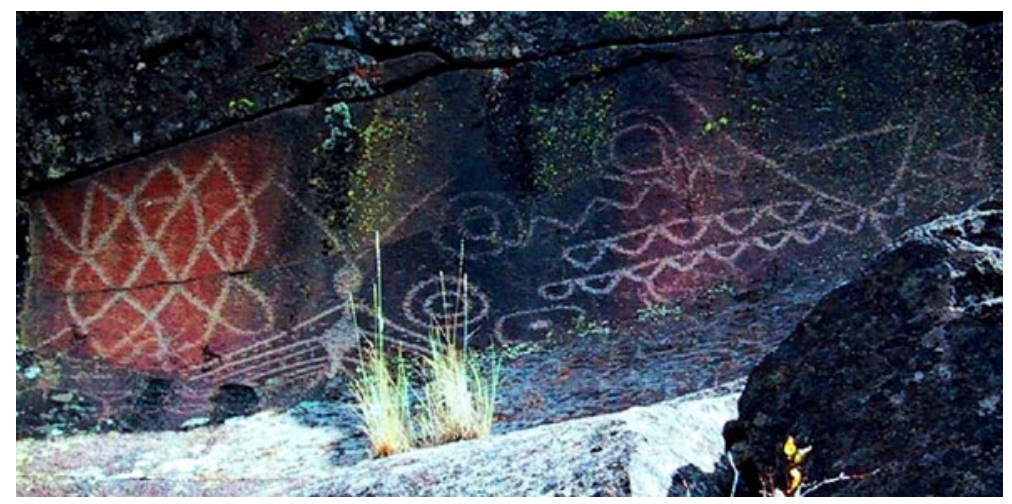

Figure 6. The central butterfly image on this panel probably depicts Aysis manifested as his primary "wife", or medicine spirit

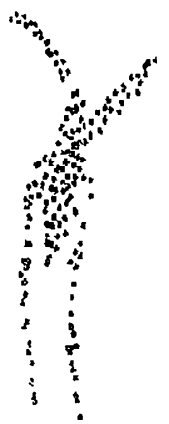

Figure 7. Grasshopper is one of Aysis' secondary "wives", making it likely that this image depicts Aysis or his medicine power

controlled these "wives" by assuming the personae of Aysis and calling them to his or her service.

Finally, a comment should be made concerning the spelling of these characters' names. Previous researchers have created their own systems of spelling for words comprising the Klamath-Modoc language. In the myths, this has resulted in each character having a variety of spellings, none of which is either correct or incorrect. Nevertheless, this has led to some confusion. Complicating this further is the difference in Klamath and Modoc dialects. The name of the chief spirit deity is pronounced G'mokamc (Kuh-mō-käm-ptch) by the Klamath using Barker's system but Kumush (Kuh-moosh) by the Modoc using Curtin's spelling. In this paper, I defer to the system used by Barker (1963) and to Klamath terminology. 


\section{Analysis and Interpretation}

My key point of this study is that some spirit-helpers utilized by shamans in specific curing rituals are the same actors portrayed in the mythical tales. The nature of their mythological exploits determined the type of supernatural power they possessed, and by extension, their utility as shamans' spirit-helpers. These mythical characters are fundamental to shamans' curing practices. In order to understand the rock art and ritual objects in terms of their mythical connotations, it is first necessary to understand the myths informing their production. Each section that follows will be headed by the appropriate paraphrased myths and followed by analyses of the rock art or ritual objects deriving from them. We begin by examining rock art along the Upper Klamath Lake.

\section{Rock Art}

\section{Latkakawas}

Latkakawas and her five brothers live on the south side of Klamath Lake. Latkakawas could make herself look like an old woman while she worked out of the house. She did this when people approached because they tended to make fun of her blue color, despite her beauty. Inside, she was young, beautiful, and blue. Young men living on the east side of the lake see her as young and beautiful, but when they try to approach, she turns old and hunchback again. Her brothers plan to move her to "the island" the next day. One young man on the west side of the lake was as blue and beautiful as Latkakawas herself. The young man's father bathed him, dressed him in fine clothes, and sent him to see Latkakawas. At the advice of his father, the boy traveled underground so Latkakawas would not see his approach. Although she sensed his approach, Latkakawas did not change herself into the old woman: she allowed him to see her as a young and beautiful blue woman. Her appearance pleased him and he returned home. Latkakawas fell in love with him. Not only was he pleasant to look at, but he had been the only person to look at her without making fun of her. He returned the next day to see her again, coming from the west. His brilliance dazzled her; for he was bright as the sun. Meanwhile, Latkakawas' brothers returned home and began pulling down the house, preparing to move. By midday Latkakawas had forgotten about him. She boarded the canoe with her brothers and started for the island. However, as they pushed off, they could not move, for the young man was holding onto the canoe from under the water. After a struggle he let them go, but he followed them under the water. One of Latkakawas' brothers mistook him for a salmon and speared him, killing him instantly. The brothers felt bad and returned to shore the next day to cremate him. After the fire had died, all that remained in the ashes was a bright 
disk. Her brothers gave the disk to Latkakawas and told her to take it to Kumush (G'mokamc), who lived in his sweat house at Nihlakshi. There he could bring the young man back to life. On her way to Kumush's lodge she gave birth to a beautiful boy. After Latkakawas arrived at the sweathouse, Kumush took the disk and proceeded to bring the young man (the little boy's father) back to life. But Kumush wanted the disk for himself and immediately willed the young man dead again. Latkakawas saw that her lover was dead and attempted to jump into the fire with her child in grief. At the last moment Kumush saved the baby but Latkakawas and the young man were burned to ashes. Kumush named the baby Aysis. Then he found the disk in the ashes and placed it in the small of his back where it became a part of him. Kumush left Nihlakshi and traveled north, hiding the child in a boil in his knee in order to conceal his treachery. On the road he stayed with two old women. They pressed the boil and Aysis came out. Later, Kumush took him to live at Tule Lake (Curtin 1912:1-7).

The image in Figure 8 is not a depiction of the character Latkakawas, but it is a reference to the story bearing the same name. In particular, the image depicts the blue boy bearing a sun disk whom G'mokamc resurrected in his sweat lodge. It will be recalled that the boy's shining disk enabled G'mokamc to resurrect him and is the same disk which G'mokamc later stole for himself. The image presented in Figure 8 shows a human form having a small head, arms, and legs, but with an exaggerated fish-like body bearing a disk on his chest. In short, we are presented with the same dilemma faced by the brothers of Latkakawas: an image of a human that can be easily mistaken for a fish. I propose that this image represents the resurrected lover of Latkakawas and therefore refers to the resurrecting power of G'mokamc.

\section{Isis (Aysis) and Yaulilik's Daughters}

In the story Aysis and Yaulilk's Daughters, the daughters of Yaulilik (snowbird) embarked on a journey to find a husband who is a good hunter. Aysis was an excellent hunter who could acquire enough deer meat to feed the world. Before departing their lodge, their mother warned her daughters that Kumush likes to dress us as his son, Aysis, and fool the unwary. Their quest took them to the lodge of G'mokamc and Aysis situated on top of a mountain. While there, G'mokamc tricked them into believing that he was Aysis, as was his custom, but the daughters eventually found him out and killed him by scratching his face with their bone head-scratchers. Outraged, Aysis beheaded them and threw their bodies into a river. Sometime later, their brother found their heads and (later) bodies while fishing and took them home. Yaulilik placed the bodies of her daughters in a basket and set them 


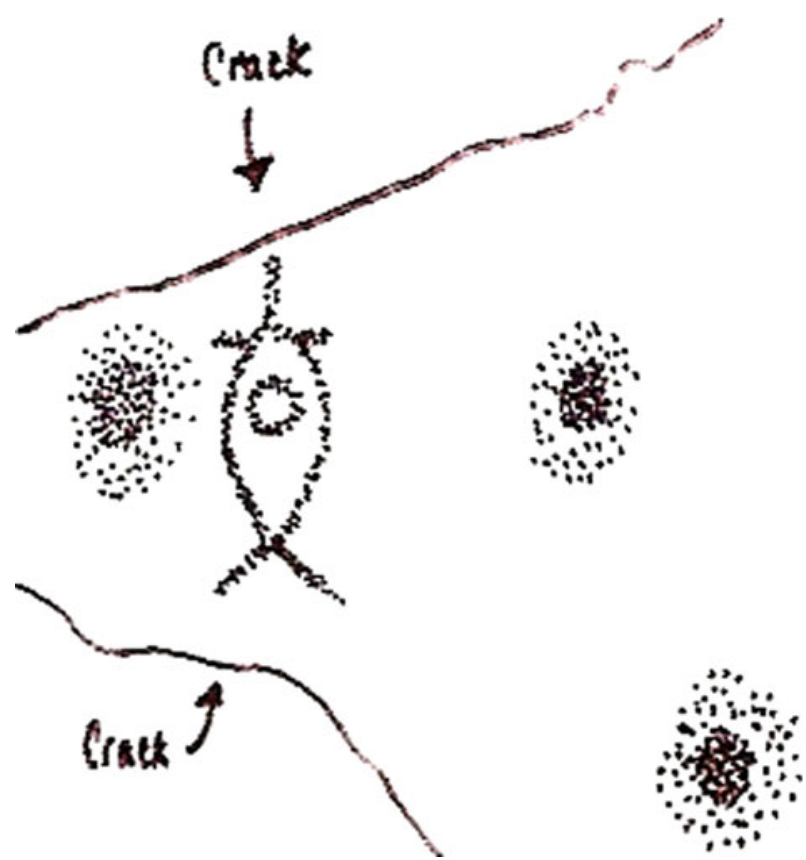

Figure 8. A human figure with a fish-like body bearing G'mokamc's sun disk. Note that the figure is surrounded by nucleated polychrome circles

inside of a sweat lodge, sealing it tightly, then set off to find their killer. While she was gone, the daughters returned to life. Meanwhile, Aysis, feeling morose over his deeds, went to the top of Mt. Shasta to weep. Upon their recovery, the daughters went to Mt. Shasta to gather seeds. While there they grew thirsty and searched for water near the gathering area. As they searched, the youngest, wisest, sister found Aysis' dead bones lying in an open field. Only his eyes were alive. Against her older sister's advice she restored Aysis to health by rubbing his bones with deer fat. Both sisters eventually became his "wives." The sisters had children by Aysis, but due to their neglect, one of the children died. Engaged, Aysis turned his wives into snow birds, destined to freeze and die. The little boy, their brother Cogatkis, he turned into a Kengkong'kongis (a medicine) whom doctors (shamans) will dream of. Upon completing this, Aysis departed to live in the north (Curtin 1912: 27-38).

As previously indicated, circular images are the most commonly depicted motif in the Klamath Basin and have been described as representations of G'mokamc, the Klamath-Modoc creator and the principal spirit-helper of shamans (Whitley et al., 2004:231-233; David 2005a:58-59; Hann and 
Bettles 2006:187). In some admittedly rare instances, G'mokamc's symbol appears with parallel lines crosscutting the enclosed center, as in the image in Figure 9. No explanation for this phenomenon has been forthcoming. I suggest here that these images depict the symbolic death of G'mokamc as brought about by the daughters of Yaulilik, who killed him by scratching his face with their bone head-scratchers in the tale (Curtin 1912:29). The red, parallel lines painted inside of the circles symbolize their scratches across G'mokamc's face. Their use of the bone head-scratchers is important to note. Spier (1930:95) reported that supplicants seeking spirit power were not allowed to touch their faces with their bare hands during their ritual ordeal. In order to scratch, they instead had to use head-scratchers to avoid this offense. Figure 10 shows sketches of head-scratchers provided by Spier (1930:70). The use of bone head-scratchers appears to have been restricted to girls, since Spier pointedly does not specify bone for boys (Spier 1930:70). That the daughters of Yaulilik carried with them bone headscratchers on their quest for a "husband" should be evidence enough to indicate that their quest for a husband was in fact a quest for spirit power. Symbolically killing G'mokamc may in fact have been necessary for acquiring the spirit power of his son Aysis, since in the tale they became his "wives." I suggest, therefore, that the images presented in Figure 9 may depict a shaman's successful acquisition of Aysis as a spirit-helper, achieved through the symbolic death of G'mokamc. The two "legs" at the base of
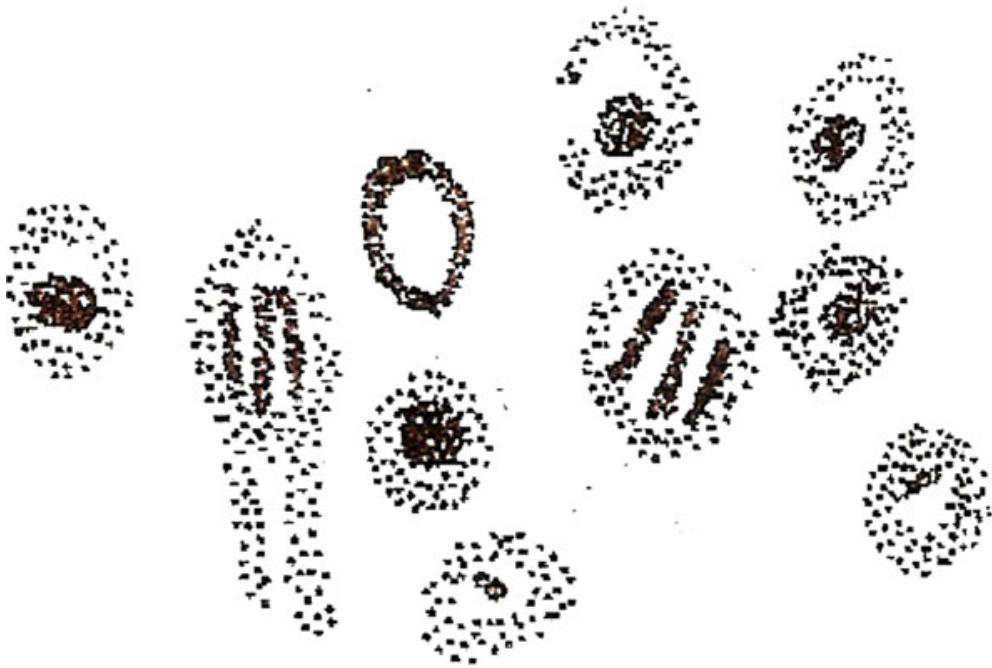

Figure 9. Red-painted lines associated with the white-painted circles represent the "scratched" face of G'mokamc 

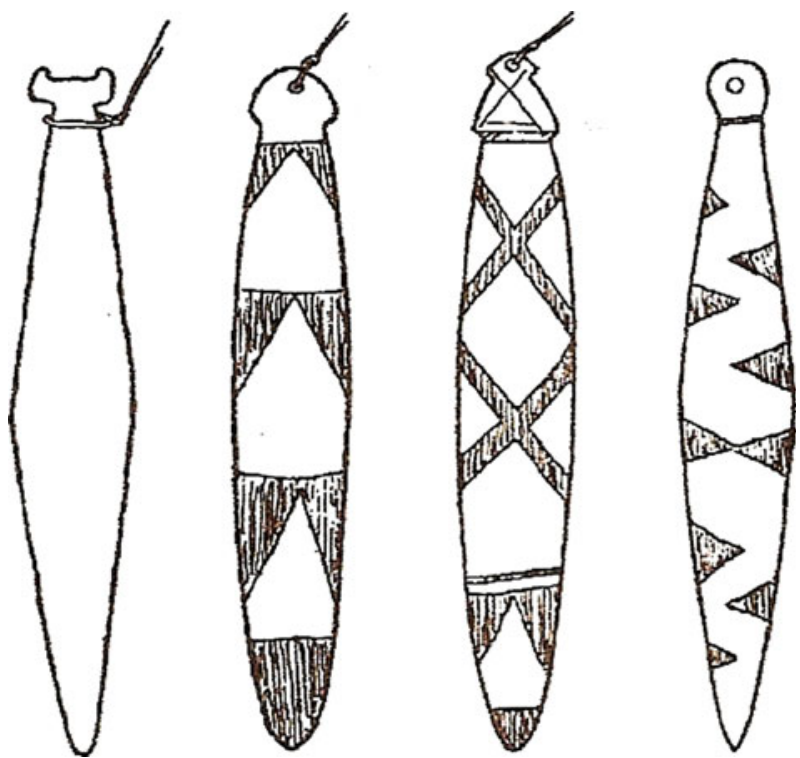

Figure 10. Bone head-scratchers used in girls' puberty rites. From Spier 1930:70, Figure 6

the "scratched" image on the lower left may well represent the headscratchers carried by each of the two daughters.

\section{Henwas}

\section{Pitoiois}

Pitoiois was a beautiful young woman who lived with her two brothers. Wus, a powerful medicine spirit, wanted her for a wife but she was afraid of him. One day while her brothers were out hunting, Wus disguised himself as a young handsome man wearing fine beaded clothes and tried to seduce her. She tried to flee but Wus overtook her and pulled her down on the ground. Out hunting with his brothers, the youngest Wulkutska brother heard Pitoiois' cries and wanted to rescue her. He failed to find her that night, but the next morning, the five Wulkutska brothers found her sitting in a valley still under Wus' control. They quickly scared Wus off with a great arrow then rushed down the valley to rescue Pitoiois. Pitoiois became the youngest brother's "wife". Leaving the valley, they took her to their lodge where their father was waiting with his servant Tskel. Their father, Old Wulkutska, was a glutton who devoured everything, including people. Warning him not to eat Pitoiois, Tskel snatched the old 
man's mortar (which he was using to pound human bones), and threw it away. The old man retrieved it and warned Tskel not to do that again since he could not "do without it". Curiously, the old man referred to his mortar as his "cap." Unable to help himself, the old man tried to harm Pitoiois almost at once. To thwart him, Tskel took the old man's mortar and threw it away. Deterred from killing Pitoiois, the old man was forced to retrieve it. On another occasion, while Pitoiois was accompanying her husband and brothers-in-law on a hunt, Old Wulkutska caused Tskel to sleep then followed after them. He watched from a mountain as his sons and Pitoiois prepared to return home. The oldest brother saw him watching, snuck around the mountain and came up behind Old Wulkutska, snatching his mortar. Angrily, he threw the mortar over four mountains. It landed in front of the Wulkutskas' lodge and Tskel woke up just in time to retrieve it. This time, he quickly took it to the creek and buried it in the mud before Old Wulkutska returned home. Frantically, Old Wulkutska called for his "cap", without which he would die. Tskel did not tell him where it was right away, and Old Wulkutska fell dead: for the mortar was his medicine. Feeling bad he had killed Old Wulkutska, however, Tskel retrieved the mortar and dried it in the sun. When he failed to fully recover, Tskel took out a stick, which he kept behind his ear, and struck Old Wulkutska repeatedly until he finally recovered. Notably, the stick was Tskel's medicine. Tskel warned Old Wulkutska he would hide his cap again if he teased Pitoiois in the future. Unfortunately, this did not change Old Wulkutska's mind. The next morning, after the brothers left to go hunting, Old Wulkutska threw his mortar at Pitoiois, trying to kill her. Tskel stopped him once again by snatching his mortar, returning it to him again with another warning. However, later, when he found out what Old Wulkutska had done, the youngest brother angrily snatched away Old Wulkutska's mortar and broke it. At that moment Old Wulkutska turned red as fire. The mortar pieces also turned red and he snatched them all up, holding them close. Right away the mortar was whole again. This made the Wulkutska brothers afraid, because they did not know how to kill the old man. Tskel told them that to kill Old Wulkutska, they had to bury his mortar in ground water. On yet another occasion, while Pitoiois was fishing, Old Wulkutska tried to kill her with his mortar again. Once again, he failed. That night in camp, Old Wulkutska joined Pitoiois and the brothers in camp. Everyone watched him for fear he would kill Pitoiois. Angrily, one of the brothers grabbed his father's mortar, and threw it into the river. Weakened, the old man threw a pounder at the youngest brother and missed. The young man threw it back, hitting and killing Wulkutska. It had been easy to kill Wulkutska because his mortar was in the water. This time, Tskel cried, saying he could not do without the old man. Pitoiois felt sorry for Tskel. When her husband asked if she could do anything for Old 


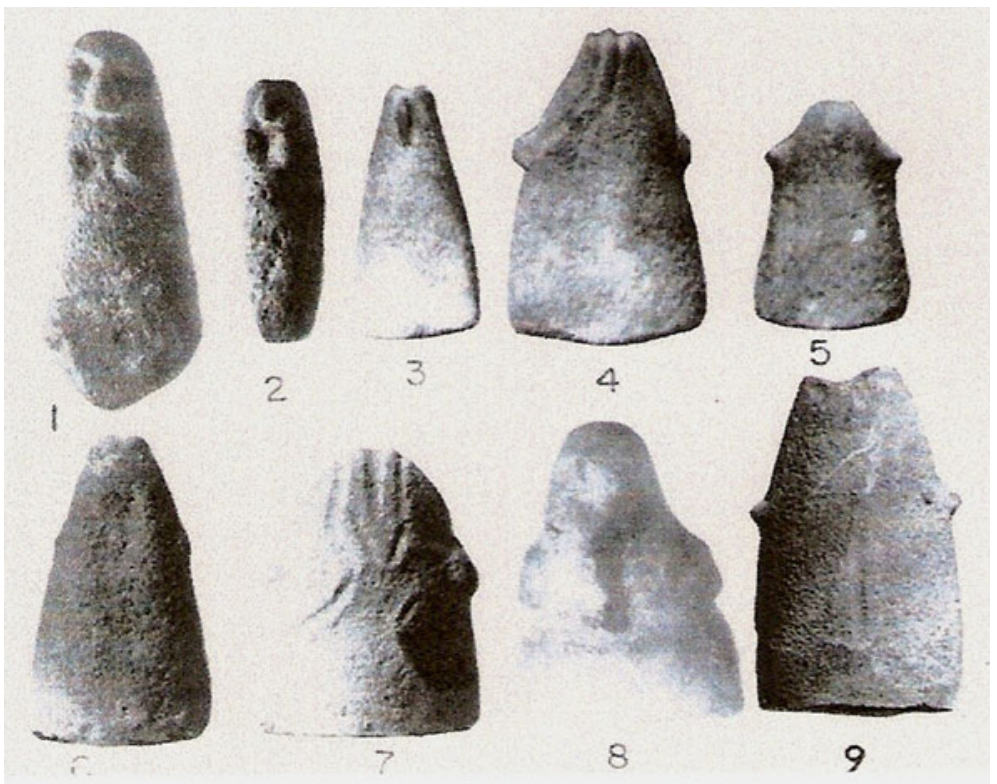

Figure 11. Carlson's henwas collection obtained from "Lizzie" Kirk. From Carlson 1959:93, Plate 1

Wulkutska, she said she could return him to life but he would be like everyone else, unable to use his mortar as his medicine. She made a grass "plate", sprinkled it with water, and then stepped over the old man five times. When he failed to fully recover, she asked Tskel to strike him with his medicine stick as he had done before. This time the old man recovered and had a "good mind" (Curtin 1912:318-332).

The henwas in Figure 11 are those Roy Carlson purchased from Klamath tribal member "Lizzie" Kirk, who told him that they were used by "Indian Doctors" for curing (Carlson 1959:88). The connection between these and "Indian Doctors" suggests that they functioned in some curing ritual that required the shaman to bury them along muddy stream banks. A casual analysis of the myth, Pitoiois, suggests that a ritual existed among the Klamath-Modoc that involved the not-so-kind character, Wulkutska, whom the shaman could prevent from causing harm (or death) only by burying his "mortar" in the water-precisely where these objects have been found!

\section{Discussion and Conclusions}

The events described in Klamath-Modoc mythic narratives harbor the spiritual perspectives of indigenous people as it pertains to both the 
landscape and the shamans' abilities to tap its supernatural power. Myths, preserved in writing, orally, and as expressions on the cultural landscape (eg. the creation of humanity at Petroglyph Point), continue to be shared widely in Klamath-Modoc society. In the past, this "common knowledge" among the tribal laity was fundamental for the shaman's curing practice; for it provided the logic that helped lay people make sense out of the rituals performed on their behalf. Invoking the life-giving powers of G'mokamc at the very place he created humanity, for instance, would certainly command significant powers of suggestion for an ailing patient who was dependent on the shaman's supernatural ability to cure. In this light, it makes sense that the behaviors exhibited by supernatural characters were emulated by the shamans as part of their curing rituals, such as Tskel's burial of Wulkutska's mortar in stream beds. Witnessing the burial of Wulkuts$k a$ 's mortar in this fashion would reasonably provide comfort for any individual diagnosed with an ailment caused by his mortar. In the myth, burying Wulkutska's mortar was the only certain way to disenfranchise him. Critical to this perspective is the notion that shamans, during the ritual performance, acted out the roles played by the hero characters of myth. All Klamath-Modoc accounts tell us that this is exactly what shamans did (Spier 1930:109). With regards to the henwas, then, it is reasonable to infer that shamans, acting ritually under the spirit tutelage of Tskel, buried henwas in stream beds as part of a curing ceremony that targeted any disease brought about by Wulkutska.

Regarding the role that the mythical landscape played in the location of rock art sites, it is important to understand that some of the outcroppings containing rock art were once living beings before Crow's laughter changed them to stone. The spirits of these powerful beings survived beyond mythical times and some, like G'mokamc, were thought from time to time to revisit the rocks that once embodied them (Gatschet 1890a:149). It was at these very sites that shamans created their art. I suggest that summoning these powerful entities was the motivating force behind the creation of the rock art. In essence, rock art served the shamans as the essential tools with which to perform their supernatural feats such as ritual curing. There was no place more appropriate for placing the art than on the very rocks where their spirits were thought to frequent and inhabit. The ritual acts of shamans brought into public and cultural existence the mythical landscape. Rock art was, in this light, another "item" of ritual paraphernalia-one that had to be created or fashioned through the application of paint, or by scraping or pecking specific images on rock surfaces. In the Klamath-Modoc cosmological sense of logic, shamans would have painted images that symbolized the the medicine tools they sought to use, such as G'mokamc's sun disk. In accordance with this, Spier identified rock art as shaman's mu'lwas, tools, or paraphernalia, and stated that it had been made by 
G'mokamc himself-the medicine spirit with which shamans most commonly identified (Spier 1930:142). As G'mokamc, Klamath-Modoc shamans painted sun disk or other symbols as part of ritual efforts to control their magic. That the Klamath Basin rock art style is dominated by circular motifs is testament to the notion that shamans, as G'mokamc incarnate, created rock art designs. Their location on the landscape derived from the spiritual logic laid out in Klamath-Modoc myth. Essentially, the places where supernatural beings lived or performed miraculous feats are the same places that shamans believed harbored the supernatural power they desired.

Although the majority of modern Klamath-Modoc people deny any knowledge of the rock art in our traditional homeland, the opposite is true for myth and the spiritual landscape. Stories of fantastic beings performing supernatural feats on the landscape are still passed on orally, and have also been codified in texts. While rock art and ritual objects purportedly remain much of a mystery, this paper has hopefully shown that the vast body of mythical tales has the potential to lead us to a fuller understanding of these aspects of our ritual heritage. Nevertheless, I also acknowledge that my approach has its limitations.

Mason (2000) was certainly correct when he stated that oral information cannot be treated like hard data in scientific research, especially since it lacks objectivity, cannot be manipulated like material objects, and is in some cases carefully controlled by cultural guardians. Given these limitations it would seem impractical to employ these myths in rock art studies, especially those that address the larger questions of the discipline. Studies such as those carried out by Swartz (1978) have eschewed the use ethnographic information in favor of more formalized methods which are, by and large, more aptly suited to addressing regional concerns, such as what design styles and rendering techniques can tell us about human migration, cultural boundaries, and inter-group relations. Work of this kind must continue. But as Hyder has noted, differing interpretations are a product of the scale of their analyses, each of which having its own type of interpretation (Hyder 2004:87). Whereas Swartz's scale was regional, mine was local (or micro-, after Hyder 2004), focusing on the rock art of a single site. Accordingly, my interpretations derived only from the data considered at the site level. It is not my point here to suggest that one approach should be sacrificed to the other. At the same time, however, I hope that my use of myth in this paper has demonstrated its potential to help address more localized concerns, such as how rock art images were relevant to the people for whose benefit they were originally created. 


\section{Acknowledgements}

I am grateful to Margaret Conkey, James Keyser, Sandra Holliman, Tom Biolsi, and Darren Modzelewski for commenting on drafts of this paper. I am also grateful for the three reviewers who helped to improve the quality of this paper. Janette Crume and Janice Miller of the Klamath Tribes assisted me greatly with the field work, and Sheryl Della-Rose transported the field crew to the site. I especially want to thank the Klamath Tribes Culture and Heritage Department for its continued support. Finally, I am grateful to the Indigenous Culture Preservation Society and Oregon Archaeological Society for their generous financial support.

\section{Open Access}

This article is distributed under the terms of the Creative Commons Attribution Noncommercial License which permits any noncommercial use, distribution, and reproduction in any medium, provided the original author(s) and source are credited.

\section{References Cited}

Abbott, H. L.

1857. Report of Lt. Henry L. Abbott upon Explorations for a Railroad Route from Sacramento Valley to the Columbia River. In Reports of Explorations and Surveys to Ascertain the Most Practicable and economical Route for a Railroad from the Mississippi River to the Pacific Ocean, Vol. 6, No. 2, pp. 1-134. Washington.

Anyon, R., T. J. Ferguson, L. Jackson, and L. Land

2000. Native American Oral Traditions and Archaeology. In Working Together: Native Americans and Archaeologists, edited by K. E. Dongoske, M. Aldenderfer, and K. Doehner. Society for American Archaeology.

Armitage, R. A., M. Hyman, J. Southon, C. Barat, and M. W. Rowe

1997. Rock Art Image in Fern Cave, Lava Beds National Monument, California: Not the AD 1054 (Crab Nebula) Supernova. Antiquity 71(1997):719-721.

Barker, M. A. R.

1963. Klamath Texts. University of California Publications in Linguistics. University of California Press, Berkeley and Los Angeles, CA.

Carlson, R.

1959. Klamath Henwas and Other Stone Sculpture. In American Anthropologist, New Series, Vol. 61, No. 1 (Feb., 1959), pp. 88-96. 
Clark, E. E.

1953. The War Between Lao and Skell: A Legend of Crater Lake. In Indian Legends of the Pacific Northwest. University of California Press, Berkeley and Los Angeles.

Cressman, L. S.

1937. Petroglyphs of Oregon. Monographs. In Studies in Anthropology, No. 2. University of Oregon, Eugene.

1956. Klamath Prehistory. American Philosophical Society, Transactions 46(4):375513.

Curtin, J.

1912. Myths of the Modocs. Little, Brown, Boston, MA.

n.d. Unpublished Ethnographic Notes on the Modoc and Klamath. National Anthropological Archives.

David, R. J.

2005a. Rock Art as Shamans' Tools: Testing and Refining Landscape Symbolism Models in the Klamath Basin. Unpublished Master's Thesis on file at Portland State University, Portland, Oregon.

2005b. Klamath Indian Rock Art Recording Project 2005: Shamanism, Myth, and Rock Art. Unpublished Report on File at the Oregon Archaeological Society Library, Portland, Oregon.

Dennison, J. S.

1878. Letter to Samuel Gatschet. Bureau of American Ethnology, Document 315. Smithsonian Institution, Washington DC.

Echo-Hawk, R. C.

2000. Ancient History in the New World: Integrating Oral Traditions and the Record in Deep Time. American Antiquity 65(2):267-290.

Eccles, R., and Patricia

2005. What About Wildlife? http://www.wildlife1.htm.

Ewers, J. C.

1981. The Emergence of the Named Indian Artist in the American West. In American Indian Art Magazine, Vol. 6, No. 2.

Fixico, D.

1998. The Invasion of Indian Country in the Twentieth Century: American Capitalism and Tribal Natural Resources. University Press of Colorado, Boulder, CO.

Gatschet, A. S.

1890a. The Klamath Indians of Southwestern Oregon. U.S. Geographic and Geological Survey of the Rocky Mountain Region, Contributions to North American Ethnology. 
1890b. The Klamath Indians of Southwestern Oregon. U.S. Geographic and Geological Survey of the Rocky Mountain Region, Contributions to North American Ethnology.

n.d. Miscellaneous Papers and Notes Collected from the Klamath and Modoc Tribes. Bureau of American Ethnology Documents 610, 1995, 2019, 2849, 2975, 3686, 3990. Smithsonian Institution, Washington (DC).

Gendler, R.

2005. A Stargazer's Full Moon. http://www.antwrp.gsfc.nasa.gov/apsd/ap00011 13.htm.

Grant, C.

1967. Rock Art of the American Indian. Thomas Y. Crowell, New York.

Hann D., J. D. Keyser, and P. M. Cash-Cash

n.d. Columbia Plateau Rock Art: A Window into the Spirit World. AltaMira Press (In Press).

Hann, D., and G. Bettles

2006. House of the Rising Sun: Using the Ethnographic Record to Illuminate Aspects of Klamath Basin Rock Art. The Oregon Archaeological Society, Portland, Oregon.

Heizer, R. F., and C. W. Clewlow, Jr.

1973. Prehistoric Rock Art of California, Volume 1-Text and Plates. Ballena Press, Ramona, CA.

Howe, C. B.

1968. Ancient Tribes of the Klamath Country. Binford and Mort Publishing, Portland, Oregon.

1979. Ancient Modocs of California and Oregon. Binford and Mort Publishing, Portland, Oregon.

1984. Sagebrush to Shakespeare. Author's Special Edition. United States of America.

Hyder, W. D.

2004. Locational Analysis in Rock Art Studies. In The Figured Landscapes of Rock Art: Looking at Pictures in Place, edited by C. Chippindale and G. Nash. University of Cambridge Press, New York, NY.

Jensen, P. M., and A. Farber

1982. Archaeological Data Recovery at CA-SIS-342. California Department of Transportation, Redding.

Keyser, J. D., and G. Poetschat

2003. The Canvas as the Art: Landscape Analysis of the Rock-Art Panel. In Pictures in Place: The Landscape of Rock-Art. Cambridge University Press, London. 
Lewis-Williams, J. D., and T. A. Dowson

1988. The Signs of All Times: Entoptic Phenomena in Upper Paleolithic Art. In Current Anthropology, Vol. 29, No. 2. Wenner-Gren Foundation for Anthropological Research. doi:10.1086/203629.

Lewis-Williams, J. D.

1990. Documentation, Analysis, and Interpretation: Dilemmas in Rock Art Research: a review of The Rock Paintings of the Upper Brandberg, Part I: Amis Gorge. By H. Pager (1989). South African Archaeological Bulletin 45:126-136. doi:10.2307/3887979.

Loring, M. J., and L. Loring

1983. Pictographs and Petroglyphs of the Oregon Country Parts I and II (2nd ed.). Institute of Archaeology, University of California, Los Angeles.

Mallery, G.

1893. Picture Writing of the American Indian. Tenth Annual Report of the Bureau of American Ethnology, 1888-1889, pp. 1-882, Washington, D.C.

Mason, R. J.

2000. Archaeology and Native North American Oral Traditions. American Antiquity 65(2):239-266. doi:10.2307/2694058.

Ray, V.

1963. Primitive Pragmatists: The Modoc Indians of Northern California. University of Washington Press, Seattle, WA.

Riddle, J.

1890. Letter to Albert Gatschet. Bureau of American Ethnology Document 3743.

Spier, L.

1930. Klamath Ethnography. In American Archaeology and Ethnology, edited by A. L. Kroeber and R. H. Lowie. University of California Press, Berkeley, CA.

Stern, T.

1966. The Klamath Tribe: A People and their Reservation. University of Washington Press, Seattle, WA.

Sterns, H. T.

1928. Lava Beds National Monument, California. Geological Society of Philadelphia, Bulletin, Vol. 26, No. 4, pp. 238-53. Philadelphia.

Swartz, B. K. Jr.

1978. Klamath Basin Petroglyphs. In Revised and Abridged, edited by J. B. Lowell and T. C. Blackburn. Ballena Press, NM.

Whitley, D. S.

1994. Shamanism, Natural Modeling, and the Rock Art of Far Western North American Hunter-Gatherer. In Shamanism and Rock Art in North America, edited by S. A. Turpin. Rock Art Foundation, Inc., Texas. 
2000. The Art of the Shaman: Native American Rock Art of Native California. University of Utah Press, Salt Lake City, UT.

Whitley, D. S., J. Loubser, and D. T. Hann

2004. Friends in Low Places: Rock Art and Landscape Symbolism on the Modoc Plateau. In The Figured Landscapes of Rock-Art: Looking at Pictures in Place, edited by C. Chippindale and G. Nash. Cambridge University Press, New York. 